Journal of

APF Command and Staff College

\title{
Examination of Household Evacuation Influencing Factors In Flood Disaster: A Case Study of Saptari Flood in Nepal
}

\author{
Praja Bhakta Shrestha, \\ E-mail: sai_bhakta@yahoo.com \\ Gangadhar Chaudhary \\ E-mail: gdc4np@gmail.com
}

\section{Article History \\ Received November 24, 2020 \\ Accepted December 4, 2020}

Keywords Disaster,

Flood, Evacuation,

Warning, Decision Making

Corresponding Editor

Ramesh Raj Kunwar

kunwar.dr@gmail.com

\begin{abstract}
Disaster, a serious disruption in functioning of society whether by natural or manmade cause can happen anywhere. Devastating seismic, hurricane, flood, drought and fire are major disaster. Mitigating disaster risk, prompt rescue and timely evacuation decision during such disaster can prevent loss of lives and properties. The evacuation decision is the choice of people to stay away from the area of risk. The study analyzes the people's perception of evacuation decisions in a flood disaster in the Saptari district of Nepal affected by Koshi River and other tributaries of it as a Disaster Risk Management. According to United Nations (2016), Management refers to "the organization, planning and applications of measure preparing for, responding to and recovering form disasters". From the flood-affected site, 246 people were randomly selected for this study and examined the factors influencing evacuation decision-making. The study analyzes the past experiences of the people and their perception. The study has explored that Gender, Destination of evacuation, warning condition, reasons for not evacuating, education, age, proximity to the River from residence, land ownership, the capacity of the people are the factors examined and found no any association with the people's decision on evacuation during the flood disaster in affected areas in Saptari district. These findings help the student, Disaster Risk Reduction field, Government policy makers and different actors to minimize the loss of lives and properties. The study also recommends for future research on victim's evacuation decision-making capability in different flood-prone area of Nepal.
\end{abstract}




\section{Introduction}

Disaster can be defined as a serious disruption of the functioning of a society, causing widespread human, material, or environmental losses, which exceed the ability of the affected society to cope by using only its own resources. (UNISDR, 2009).As per causality Disasters, are natural or manmade. The major disasters are an earthquake, epidemics, flood, landslide, volcanic eruptions, gas leakage, fire, heat and glacier lake outburst etc. Climate changed, rapid urbanization, migration and environmental degradation and exposed populations to greater risks to events and their impacts (Djalante, Holley, \& Carnegie, 2013; in Raikes, Smith, Jacobson, Baldwin, 2019).

The natural disasters like Earthquakes, Landslides, Floods, Hurricane etc., have become the recurring disasters all over the world. Nepal is also vulnerable to the natural and manmade disaster. Every year there is a loss of huge number of lives and property. Every year, Nepal is facing landslides, earthquakes, windstorms, hailstorms, fires, floods, droughts, and risk of glacial lake outburst floods (MOHA, 2018, p. 1). Mostly the low land part of the country has been affected by flood damaging productive agricultural fields, and causing the loss of lives and properties as well.

Due to the geographical structure, plain region of Terai are mostly affected by floods which is the most common of the natural disasters, gravely affecting the life of humans and the environment. The major floods of Kosi River in 2008 and other subsidiary Rivers have affected almost every parts of Terai region during monsoon season. During the rainy season, most of the districts of Terai are affected. Flood disaster management implies not letting the overrun of water flow suddenly and intensely in the drainage network. After the unprecedented floods of 1954, flood management works were taken up in a planned manner ... (Mohita, n.d.).Some of the major steps of flood disaster management are: (1) Flood Forecasting; (2) Reduction of Runoff; (3) Reducing Floods Peaks by Volume Reduction (Constructing Dams and Detention Basins) ; (4) Reducing Flood Levels ; (5) Protection Against Inundation (Construction of Embankment ) ; and (6) Flood Plain Zoning (Mohita, n.d.) .

Nepal is part of the Himalaya-Ganga, the generic name for a high land-low land interactive system consisting of the highest mountain chain on this planet (Verghes, 1990; in Dixit, 2003). The extreme behavior of nature ranges from sudden and high intensity monsoon rain falls to shift of continental plates. More than 6,000 Rivers and streams are flowing from north to south in In the Himalaya-Ganga the variety of topographic and the climatic types contain and abundance of ecological niches harboring widely diverse species of flora and fauna. During the monsoon cloudburst, landslides, mass movements and the flash floods are common in mountain (Dixit, 2003). Among these, the snows fed perennial River basins are the Koshi, Narayani, Karnali, and Mahakali. During the monsoon (June-September), the Rivers flow increased which cause damage to the settlements, crop lands, people and livestock. The reasons of floods are natural as well as manmade(World Bank, 2012, p. 80). 
These Disasters has a risk factor of potential losses in livelihoods, properties and services in a particular community or society over some specified time period. Disaster risk is the product of the possible damage caused by a hazard due to the vulnerability within a community. It should be noted that the effect of a hazard would affect communities differently (Von, 1999, P.35). The level of the coping mechanisms and resilience capacity of society depends on the risk factor. Therefore, Poor communities are in more risk than developed communities.

It is worldwide accepted that only effective disaster preparedness can reduce the impact of the disaster and risk. One of the significant components in the Disaster risk management(DRM) is an evacuation plan. It develops to ensure the safest place and protect the property and lives in danger. The negligence or unfamiliarity of the evacuation plan by people in disaster affected zone has caused many people to lose their lives. Not realizing the importance of evacuation plan people at risk could not decide either to evacuate or not even though they receive the warning message timely.

In recent years, there have been lots of efforts done by Government of Nepal to reduce the increasing risks associated with floods and other disaster. Timely evacuation of victims is an important action as a mitigation measure to decrease the amount of damage caused by floods. Rapid evacuation is an important factor as experienced in Koshi floods in year 2008 and other natural disaster in the past. Early warning system, increasing awareness, timely response and experience can prevent a huge loss of life and property.

The researcher tries to explore the perception of people about the evacuation in the flood disaster affected areas in Saptari district. In this research paper, the authors examine the essential factors influencing the decision to take evacuation by the people resided in the Saptari district and affected by the Koshi River. The factors identified are categorized in disaster risk management concepts, including risk assessment, risk information, and risk perception. Risk perception is an essential factor in deciding a flood hazard. Kasperson et al. (1988) stated that risk is calculated based on the probability of events and magnitudes of the specific consequences, but the risk perception revealed the person's conception of risk that influences the risk, familiarity with the risk, and public responses to hazards.

Still there is a room for in-depth research on people's evacuation behaviour to identify the crucial factors that lead people to make decision. These findings from the study help policymakers, DRM planners, Social scientists, and government bodies to better understand what is happening during flood disasters with people at risk and make better evacuation plans accordingly. Golshani (2019) experienced that effective evacuation strategies are vital to alleviate the damage and fatality caused by disasters. It helps predict the public responses or their evacuation behaviour and optimize the evacuation procedure from the affected areas. 


\section{Review of literature}

Sendai Framework (2015) articulates the following: the need for improved understanding of disaster risk in all its dimensions of exposure, vulnerability and hazard characteristics; the strengthening of disaster risk governance, including national platforms; accountability for disaster risk management; preparedness to "Build Back Better"; recognition of stakeholders and their roles; mobilization of risk-sensitive investment to avoid the creation of new risk; resilience of health infrastructure, cultural heritage and work-places; strengthening of international cooperation and global partnership, and risk-informed donor policies and programs, including financial support and loans from international financial institutions. There is also clear recognition of the Global Platform for Disaster Risk Reduction and the regional platforms for disaster risk reduction as mechanisms for coherence across agendas, monitoring and periodic reviews in support of UN Governance bodies.

When the flow of water increases in River canal beyond their carrying capacity, flood will occur. Flood is a great flow of water, causing overflow and inundation (Chambers, 1981 cited in Fleming \& Frost, 2002, p. 1).Flood is covered with water especially in a way that causes problems. Generally, flood is unusual and rapid growth of water which occur mainly due to heavy rainfall or flash flood unable to manage excess water in its water course.

Nepal's fragile geological conditions, topographical extremities, climatic extremities and seismic activities, population growth, poverty, illiteracy, deforestation, in proper land use changes and developmental activities such as infrastructure construction and urbanization are making it vulnerable to several natural disasters. Heavy rainfall in central and eastern regions of Nepal during 19-21 July, 1993 had disastrous consequences with heavy loss of life and property as well as damages to infrastructures by floods, landslides and debris flows. In 1993, $87 \%$ of the total deaths of human life occurring in the country had resulted from floods and landslides. (Yogacharya, 2008, p.1).

Government of Nepal has developed various legal and institutional arrangements to develop an umbrella policy for Disaster Risk Reduction plan taking into account of the lessons learnt and experiences gained from the past experiences. In this context, recently approved and enacted Local Government Operation Act 2017 and Disaster Risk Reduction and Management Act 2017, are the latest major legal arrangements. In addition, Natural Disaster Relief Committees established from the center to the local level as per the law, various agencies and institutes of the Government of Nepal can be taken as important institutional arrangements. (MOHA, 2018, p.3). These new arrangements will help to reduce potential risks in disaster.

There are more than 6000 Rivers and streams flow with high velocity from the north towards the south in Nepal (Poudyal, 1999). During the monsoon season, heavy rainfall occur which causes destructive flood, landslide and debris flow. Unplanned settlements and physical constructions without due consideration to the natural hazards are prime reasons of aggravating destruction. Each year such types of disasters cause the losses of high number of human life and properties. 


\section{Methodology}

This study concerns human behaviour using the survey method. The survey interview was structured to focus on three topics: individual information including demographic and socio-economic characteristics and experience with evacuation drills. This research aimed to examine the evacuation decision among households in flood disasters. The study explored the perception and responses of household members resided in frequently occurring of flood disasters in the Saptari district in Nepal.

The sample of 246 households has selected and field survey has been conducted during September to October 2018. The Descriptive survey method applied in this research. Sampling was selected randomly and household survey was conducted in the selected sites.

\section{Data collection and analysis}

The primary data was collected with the interview from the household survey. The interview was used to gather qualitative data about the previous experience of evacuation decision. The secondary data was collected consulting other related expertise. Reports of Nepal government bodies, national and international organisation, books, journals, research paper, magazines, newspaper and online materials were used as secondary sources of information. Qualitative data analysis has been used to interpret the results of this study. Data analysis involved the interpretation of data and analysed through use of statistical tools.

\section{Results and discussions}

The assessment survey interview was conducted in Saptari district mostly with the people in flood vulnerable area. The focused group was interviewed focusing their decision making and their perception on evacuation based on their gender, age, location, occupation, education, family type, and socio-economic status.

\section{Demography of Saptari district}

Saptari is situated at outer Terai districts in province no 2. The district covers an area of 1,363 square $\mathrm{km}$. According to the census, the number of population is 639,284 which make it the 10th most populated district of Nepal (CBS, 2012). Economy is largely dependent on agriculture and remittances. Saptari is renowned for its agricultural output and is bordered on the east by the massive Koshi River. 


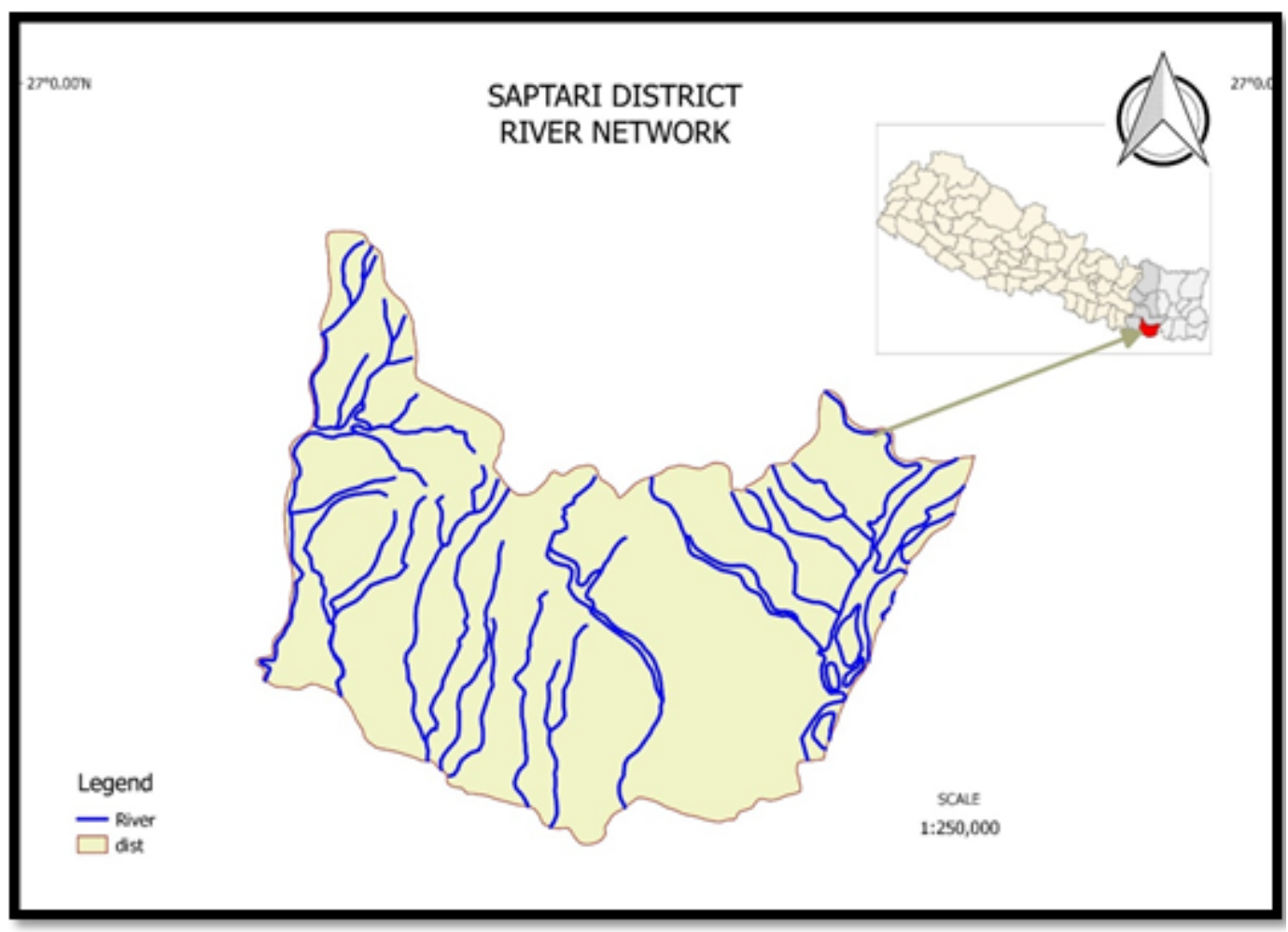

Figure 1 Study Area, Saptari District, Source:-Digitized Google Map by Researcher

Koshi is a trans-boundary River which flows through Tibet, Nepal and India. It drains the northern slopes of the Himalayas in Tibet and the southern slopes in Nepal. Koshi River is located in the eastern part and provides irrigation to the Saptrai district.The district is receiving flood from the major Koshi River and many tributaries like Sundari Khola (River), Triyuga, Mahuli, Balan, Bhutani, Khadak, Sutani, Kazara, Ghodadah, and Bhaluwahi, which brings devastating flood causing substantial financial losses and disturbs the human lives. The flash flood in Khado Rivers continuously affected the adjacent villages, Launiya, Tilathi, and other villages. These villages were taken for the study purpose. Most of the villages in Saptari district flooded every year due to heavy rainfall in the upstream mountains. The flood caused severe damage to infrastructures, standing crops and livestock. The Siwalik ranges have been heavily deforested, encroached, and deteriorating the monsoon, causing flash floods in the central-southern part of the Saptari district.

The breach of the Koshi embankment occurred during the summer flood in 2008. The flood discharge on 18 August 2008 was about 4,250 $\mathrm{m}^{3} / \mathrm{s}$ at the time of the breach occurred (UNESCO, 2009). The breach of the eastern embankment of the Koshi Barrage at Paschim Kusaha Village of Sunsari , created havoc for population living around Sunsari and Saptari district. 


\section{Risk perception}

Table 1 summarized the risk perception among gender, influencing the evacuation decision each category's frequency displayed in the table.

Table 1 Respondents Evacuation Decision

\begin{tabular}{|l|ll|c|}
\hline \multirow{2}{*}{$\begin{array}{c}\text { Gender } \\
(\mathbf{N}=\mathbf{2 4 6})\end{array}$} & \multicolumn{2}{|c|}{ Evacuation Decision } & \multirow{2}{*}{ Total } \\
\cline { 2 - 3 } & \multicolumn{2}{|c|}{ Yes } & \\
\hline Male & $(22) 9.4 \%$ & $(213) 90.6 \%$ & (235) $100 \%$ \\
\hline Female & $(1) 9.1 \%$ & $(10) 90.9 \%$ & (11) $100 \%$ \\
\hline
\end{tabular}

Source: Own Research

Out of a total of 235 male respondents, $9.4 \%$ of respondents took quick decisions to evacuate from the place of residence during a flood disaster after receiving a warning message from different sources. The rest of the male respondents (90.6\%) did not seem able to make an appropriate decision regarding evacuation. The data revealed that most of the male respondents could not take the evacuation decision. Similarly, among the female respondents, $9.1 \%$ of the female decided towards the evacuation, while $90.9 \%$ could not make any decision. The majority of Males and Females in the study area could not decide for the evacuation during a flood disaster.

From a gender perspective, $95.7 \%$ Male and $4.3 \%$ of the female respondents decided to evacuate during the disaster, respectively. Comparing the data among the decision-makers during the evacuation, the majority of men can decide on evacuation in comparison to females. On the other hand, within the group of respondents not making a decision, the majority of males $(95.5 \%)$ rather than females $(4.5 \%)$ have a negative approach to evacuation decisions.

\section{Information sources deciding on evacuation during flood}

The warning messages have been received from either Meteorological Department or Ministry of Home Affairs (Chief District Office) or Neighbours or from Social Media, or broadcasted through different media (Mobile cell phone companies through SMS, Radio, TV, Local Government Agencies, I/NGOs) in the context of Nepal. With the coordination of Mobile cell phone companies (NTC \& NCELL), Government of Nepal started disseminating warning messages through mobile phones. Other sources of communication are relatives and peoples living in upstream. 
Similarly, when the water level reaches a danger level, the trained person gives signal erecting a red flag showing alertness to the people at risk. Some of the sources available to the rural people in flood-affected areas were taken for study purposes, as tabulated below.

Table 2 Information Source of flood Disaster

\begin{tabular}{|l|l|l|l|}
\hline \multirow{2}{*}{$\begin{array}{c}\text { Trust on Information of Sources to decide for } \\
\text { evacuation }\end{array}$} & \multicolumn{2}{|c|}{ Responses } & \multirow{2}{*}{$\begin{array}{c}\text { Percent } \\
\text { of Cases }\end{array}$} \\
\cline { 2 - 3 } & $\mathbf{N}$ & Percent & \\
\hline Religious Leader & 1 & $0.1 \%$ & $0.4 \%$ \\
\hline Local Leaders & 218 & $24.5 \%$ & $88.6 \%$ \\
\hline Relatives & 233 & $26.2 \%$ & $94.7 \%$ \\
\hline TV/Radio & 14 & $1.6 \%$ & $5.7 \%$ \\
\hline Local Volunteers & 164 & $18.4 \%$ & $66.7 \%$ \\
\hline Mobile Phone SMS & 14 & $1.6 \%$ & $5.7 \%$ \\
\hline Flag & 246 & $27.6 \%$ & $100.0 \%$ \\
\hline Total & 890 & $100.0 \%$ & $361.8 \%$ \\
\hline
\end{tabular}

Source: Own Research

The respondents mostly got information regarding the flood disaster from observing the flag, relatives, local authority and local leaders. The erection of the flag on the Koshi Dam is still active when the water level reaches the danger level. Out of 246 respondents, $100 \%$ believed that they observed or got the information about the erection of the flag and made a decision whether evacuate or not. A total of $94.7 \%$ of the respondents received a message from their relatives regarding the flood situation information. Similarly, $88.6 \%$ of the respondents believed that they got a warning message from the Local leaders.

\section{Evacuation destination}

It is widely known that evacuation destination can affect their decision making and the same logic can be applied to decision making regarding evacuation in an emergency caused by a Flood.

Table 3 Evacuation Destination identified

\begin{tabular}{|l|l|l|}
\hline \multirow{2}{*}{$\begin{array}{l}\text { Evacuation identified by } \\
\text { the Respondents }\end{array}$} & Destination & Responses \\
\cline { 2 - 3 } & $\mathrm{N}$ & Percent \\
\hline On the Road & 31 & $12.6 \%$ \\
\hline On Embankment & 119 & $48.4 \%$ \\
\hline Nearby School & 28 & $11.4 \%$ \\
\hline Relative Houses & 60 & $24.4 \%$ \\
\hline Religious Places & 2 & $0.8 \%$ \\
\hline Government Located place & 6 & $2.4 \%$ \\
\hline Total & 246 & $100 \%$ \\
\hline
\end{tabular}

Source: Own Research 
Findings from the table 3 showed that out of 246 respondents, $48.4 \%$ of the respondents willing to take the shelter at the embankment during the flood. Meanwhile, $24.4 \%$ of the respondents used nearby schools and relatives house as a shelter in which the plinth level is high to prevent flooding. Similarly, $12.6 \%$ had found the nearby road a refuge during the flood if they had to evacuate.

It is imperative to gain prior knowledge or experience of evacuation places or information delivered by the authority about such plan. Families could not take the proper evacuation decision when they don't know the evacuation route and destination. The household's evacuation choice is statistically associated with the origin, destination, attitude, number of buildings and number of designated shelters. Hence, they confirmed that the evacuation destination and safe route plays a vital role in deciding on evacuation.

\section{Reasons not to evacuate}

There are various reasons not to evacuate during the flood disaster. Mostly, disabled people are not able to evacuate themselves in an emergency. Baker (1991) suggested that to understand the people's evacuation decision, it is important to know the household's perception of reasons not evacuate. The reason for not evacuation may vary so that the multi-choice responses survey was conducted. Therefore, the reasons for not taking evacuation decisions are tabulated below.

Table 4 Reasons not to evacuate during flood disaster

\begin{tabular}{|l|c|c|c|}
\hline \multirow{2}{*}{ Reasons Not to Evacuate } & \multicolumn{2}{|l|}{ Responses } & Percent of \\
\cline { 2 - 3 } & N & Percent & Cases \\
\hline Too far Evacuation Destination & 177 & $15.4 \%$ & $72.0 \%$ \\
\hline Huge crowd in Evacuation Place & 218 & $19.0 \%$ & $88.6 \%$ \\
\hline No access to the Evacuation Place & 233 & $20.3 \%$ & $94.7 \%$ \\
\hline Not enough time to go for evacuation & 200 & $17.4 \%$ & $81.3 \%$ \\
\hline Insecure or Lack of Safety & 164 & $14.3 \%$ & $66.7 \%$ \\
\hline Theft of own property when leaving & & & \\
\hline the house & 155 & $13.5 \%$ & $63.0 \%$ \\
\hline Total & 1147 & $100.0 \%$ & $466.3 \%$ \\
\hline
\end{tabular}

Source: Own Research

Some of the reasons not to evacuate in the Saptari flood presented in Table 4.The table analysed the responses and cases for reasons not deciding for evacuation during the flood. The total responses (1147) and each case wise responses are presented. The percentage of cases gives the findings of each case as specified. $20.3 \%$ of the responses indicated access to the evacuation place obstructed by the flood water and unable to reach there. $19.0 \%$ of the responses found huge crowed in the evacuation sites, so they were not willing to take shelter in the crowed evacuation place. $17.4 \%$ of the responses showed that they had 
no time to evacuate with their belongings. They took place in the safe areas in their own houses. Similarly other responses, $15.4 \%$ indicated evacuation place too far from their residence, $14.3 \%$ of responses came for insecurity or lack of safety in the unknown places, and $13.5 \%$ of the responses came that they could not leave their houses due to theft of their property. The majority of responses fall on no access to the evacuation sites followed by the crowded environment in evacuation places and insufficient time to prepare for the evacuation.

\section{Other factors}

The people feel secure when they did not get a real threat or warning about the flood disaster. The source of warning may be from officials, leaders and friendship through different means. The family perceived the real warning, then only they decide to evacuate. The majority of the literature concluded that the larger the perceived threat, the greater the probability of deciding on evacuation.

The old aged person and children decide to evacuate quickly(Fischer, et al., 1995, p. 35). But in the case of the Saptari district, the majority of all aged group people could not take evacuation decisions on time. The old aged, sick people cannot be evacuated at the time of flood warnings and other family members could not discard them which hampered evacuation. When an extended family is poorly organized, they couldn't decide timely.

The other factor considering for evacuation decision is based with the proximity of the respondents' residence from the nearby Rivers. Meanwhile, $92 \%$ of the respondents failed to decide regarding evacuation having their residences more than $100 \mathrm{~m}$ to $500 \mathrm{~m}$, and $90 \%$ of the respondents seem not able to make a decision even their residents are less than $500 \mathrm{~m}$ from the spot. Hence, perception and belief of the inhabitants to decide evacuation play role during the flood.

$94 \%$ of the respondents among the land owners and $89 \%$ of the non-landholder also did not take any decision regarding the evacuation during the flood disaster as well. It means there is no influence of landholding with the evacuation decision. They might think that they can diverged the flood water with their presence during the flood and take initiation to protect their land. The landless people have a fear of encroachment the land by others.

Another factor that showed the relation between the Disaster risk reduction (DRR) training received and their capability to make evacuation decisions. Among the DRR training received respondents, $52 \%$ answered that they took evacuation decisions while rest was unable. Similarly, from the respondents who did not receive any DRR training, $94 \%$ could not decide on evacuation. It gives the scenario that DRR training plays a vital role in deciding on the evacuation. 


\section{Conclusion}

Socio-economic status, such as household income and housing type could be critical factors associated with making evacuation decisions; high-income earners are more likely to evacuate. Evacuation decision is an important component in planning. It helps in reducing the loss of lives and properties and saves substantial financial losses. Therefore, careful examination of the factors influencing the evacuation decision must be done. But the perception of peoples at risk varies from place to place, on level of risks, type, and nature of the disaster, which may vary the impacts on the people, and ultimately the evacuation decision, may vary. In this study, the authors examine the household's evacuation decision that may be influenced by different factors in households residing in the Saptari district and impacted by the flood from the Koshi River and its tributaries flowing through these areas.

The findings emerged from examining various variables Gender, Evacuation destination, reason not to take evacuation decision, education, age, distance from the spot to residents, family types, and DRR training received. The evacuation decision depends upon the individual perceptions, personnel situation, individual characteristics, and how and in what condition the information is perceived. But the individual perception also depends upon the previous experience of the disaster, which builds their capacity to assess flood risk. The reliability and validity of past warning messages from the different sources are also important in the evacuation decision-making. Most people do not believe whether forecasting because the message gives the probability of rainfall events and not the real risk that may happen. Hence, people do not take it seriously. They mostly depend upon the message received from friends and their relatives.

Similarly, the perception of individuals may vary from person to person. But in the study area, people are always at risk of flood, and every year they received flood disaster, the factors did not influence the evacuation decision making. Hence, further additional research regarding evacuation plans based on risk perception, risk information, and risk communication must be conducted in all disaster-prone areas to generalize the above results.

\section{References}

Baker, E. (1991). Hurricane evacuation behavior. International Journal of Mass Emergencies and Disasters, 9(2), 187-310.

Bateman, J. M., \& Edwards, B. (2002). Gender and evacuation: A closer look at why women are more likely to evacuate for hurricanes. Natural Hazards Review, 3(3), 107-117. https://doi.org/10.1061/(ASCE)1527-6988(2002)3:3(107).

Central Bureau of Statistics. (2012). National Population and Housing Census 2011.

Dhakal S. (2013). Flood hazard in Nepal and new approach of risk reduction. International journal of landslide and environment, 1(1), 13-14. 
Dixit,A.( 2003).Floods and vulnerability; Need to re think flood management . Natural Hazards,28,155-179.

Fischer, H. W., Stine, G. F., Stoker, B. L., Trowbridge, M. L., \& Drain, E. M. (1995). Evacuation behaviour: Why do some evacuate, while others do not? A case study of the Ephrata, Pennsylvania (USA) evacuation. Disaster Prevention and Management: An International Journal, 4(4), 30-36. https://doi.org/10.1108/ 09653569510093414.

Fleming, G. (Ed.). (2002). Flood risk management: Learning to live with Rivers. Thomas Telford.

Islam,R., Kamaruddin,R., Ahmad,S.A.,Jan,S.J. \& Anuar,A.R.(2016).A Review on Mech anism of Flood Disaster Management in Asia. International Review of Management and Marketing,6(1)29/52 .

Kasperson, R. E., Renn, O., Slovic, P., Brown, H. S., Emel, J., Goble, R., Kasperson, J. X., \& Ratick, S. (1988). The Social Amplification of Risk: A Conceptual Frame work. Risk Analysis, 8(2), 177-187. https://doi.org/10.1111/j.1539-6924.1988. tb01168.x.

Lee, D., Yoon, S., Park, E.-S., Kim, Y., \& Yoon, D. K. (2018). Factors Contributing to Di saster Evacuation: The Case of South Korea. 16.

MOHA. (2018). Nepal Disaster Report 2017: The Road to Sendai, Government of Nepal (pp. 1-67).

Mohita.N. (, n,d).Flood disaster management : 6 major steps of flood disaster management. https://www.yourarticlelibrary.com/disasters/flood-disaster-management-6-ma jor-steps-of-flood-disaster-management/14062

MOHA.(2018).National Policy for Disaster Risk Reduction.

National Planning Commission. (2017). Nepal Flood 2017: Post Flood Recovery Needs Assessment. Government of Nepal. www.npc.gov.np.

Poudyal, M.B. (1999). Nepal Country Report. Kathmandu: MOHA.

Raikes,J., Smith,T.F., Jacobson,C.,\&Baldwin,C.,2019).Pre-disaster planning and preparedness for flood and droughts : A systematic review. International Journal of Risk Reduction, 36,101207

UNESCO on behalf of OCHA and UNCT, Nepal (2009). Report of the Rapid Hazard and Risk Assessment Post-Flood Return Analysis. Nepal, v+104pp.

United Nations. (2016). Report of the open-ended intergovernmental expert working group on indicators and terminology related to disaster risk reduction, paper presented at 71stSession (A/71-6644)

United Nations. (2015).Sendai Framework for Disaster Risk Reduction 2015-2030. 
UNISDR. (2009).Terminology on disaster risk reduction. Retrieved from http://www.pre ventionweb.net/files/7817_UNISDRTerminologyEnglish.pdf.

Von, K. (1999). A new concept of risk. Cape Town: Periphery Publications.

World Bank. (2012). Disaster Risk Management in South Asia: A Regional Overview (pp. 1-32).

Yogacharya, K.S. \& Gautam, D. K. (2008).Floods in Nepal: Genesis, Magnitude, Frequency and Consequences. Kathmandu: Society of Hydrologists and Meteorologists- Nepal. 